\title{
COVID-19 Tanılı Hastaların Risk Faktörleri Açısından Değerlendirilmesi
}

\section{Evaluation of Patients Diagnosed with COVID-19 in Terms of Risk Factors}

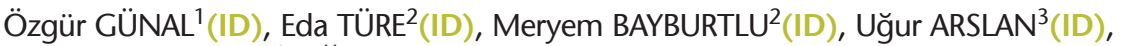 \\ Mehmet Derya DEMIRAĞ ${ }^{4}$ (ID), Mehmet Hakan TAŞKIN ${ }^{5}$ (ID), Sırrı KILIÇ ${ }^{1}$ (ID) \\ 1 Sağıık Bilimleri Üniversitesi, Samsun Eğitim ve Araştırma Hastanesi, Enfeksiyon Hastalıkları ve Klinik Mikrobiyoloji \\ Kliniği, Samsun. \\ ${ }^{1}$ Health Sciences University, Samsun Training and Research Hospital, Clinic of Infectious Diseases and Clinical Microbiology, \\ Samsun, Turkey. \\ 2 Sağlık Bilimleri Üniversitesi, Samsun Eğitim ve Araştırma Hastanesi, Aile Hekimliği Kliniği, Samsun. \\ 2 Health Sciences University, Samsun Training and Research Hospital, Clinic of Family Medicine, Samsun, Turkey. \\ ${ }^{3}$ Sağlık Bilimleri Üniversitesi, Samsun Eğitim ve Araştırma Hastanesi, Kardiyoloji Kliniği, Samsun. \\ ${ }^{3}$ Health Sciences University, Samsun Training and Research Hospital, Clinic of Cardiology, Samsun, Turkey. \\ ${ }^{4}$ Sağlık Bilimleri Üniversitesi, Samsun Eğitim ve Araştırma Hastanesi, İç Hastalıkları Kliniği, Romatoloji Bölümü, \\ Samsun. \\ ${ }^{4}$ Health Sciences University, Samsun Training and Research Hospital, Clinic of Internal Medicine, Clinic of Rheumatology, \\ Samsun, Turkey. \\ ${ }^{5}$ Sağlık Bilimleri Üniversitesi, Samsun Eğitim ve Araştırma Hastanesi, Klinik Mikrobiyoloji Kliniği, Samsun. \\ ${ }^{5}$ Health Sciences University, Samsun Training and Research Hospital, Clinic of Clinical Microbiology, \\ Samsun, Turkey.
}

Makale Atıfı: Günal Ö, Türe E, Bayburtlu M, Arslan U, Demirağ MD, Taşkın MH ve ark. COVID-19 tanılı hastaların risk faktörleri açısından değerlendirilmesi. Mikrobiyol Bul 2020;54(4):575-582.

\section{ÖZ}

Koronavirüsler, insan ve hayvanlarda üst ve alt solunum yollarında hastalık oluşturan RNA virüsleridir. Son olarak Aralık 2019 tarihinde Çin'in Wuhan kentinde pnömoni olgularına neden olan yeni bir koronavirüs saptanmıştır. Kısa süre sonra virüs" severe acute respiratory syndrome coronavirus-2" olarak tanımlanmış ve Dünya Sağlık Örgütü, hastalığa "coronavirus disease-2019 (COVID-19)" adını vermiştir. Ülkemizde ise ilk olgular mart ayının ikinci haftasında görülmeye başlanmıştır. Bu çalışmada, COVID-19 tanısıyla yatan hastaların demografik özellikleri ve risk faktörlerinin araştırılması amaçlanmıştır. Çalışmamıza 53'ü kadın, 47'si erkek toplam 100 hasta dahil edilmiştir. Çalışmaya dahil edilen hastalar kayıt sisteminden rastgele seçilmiş ve bilgileri retrospektif olarak değerlendirilmiştir. Hastaların yaş ortalaması 54.42 (20-90) yıl olarak belirlenmiştir. Hastalığa yakalanma açısından risk faktörleri araştırıldığında; 46 hastada en az bir risk faktörü olduğu ve bu risk faktörlerinin de COVID-19 hastası ile sosyal ortamda yakın temas (\%30) ve son 14 gün içerisinde şehir dışına seyahat (\%16) etme olduğu belirlenmiştir. Hastalarımızda en sık rastlanan semptomlar; öksürük (\%93), ateş (\%42), dispne (\%22), halsizlik (\%8), boğaz ağrısı (\%7), ishal (\%6), baş ağrısı (\%5) ve balgam (\%2) olarak belirlenmiştir. En sık saptanan komorbiditeler ise hipertansiyon (\%42), diabetes mellitus (DM) (\%21), konjestif kalp yetmezliği (\%10), alerjik astım (\%7), kronik obstrüktif akciğer hastalığı (\%6), romatoid artrit (\%3), koroner arter hastalığı (\%2), solid organ tümörü (\%2), depresyon (\%1) ve epilepsi (\%1) olarak saptanmıştır. Yoğun bakımda izlenen hastalarımızın $(n=15)$ yaş ortalaması $65( \pm 11.46)$ yıl, 
serviste takip edilen hastaların ( $n=85$ ) yaş ortalaması $52.55( \pm 16.35)$ yıl belirlenmiş ve aradaki bu fark istatistiksel olarak anlamlı bulunmuştur $(p=0.006)$. Bu iki grup komorbidite açısından karşılaştırıldığında, DM varlığı yoğun bakım hastalarında \%40 ( $n=6$ ) ile daha yüksek olup, fark istatistiksel olarak anlamlı bulunmuştur $(p=0.05)$. Ayrıca yoğun bakımda yatan hastaların çoğunluğunun erkek olduğu tespit edilmiştir [ $n=11,(\% 73)](p=0.03)$. Sigara içmenin hastalık ciddiyeti açısından bir risk faktörü olup olmadığı değerlendirildiğinde, yoğun bakımda yatan 11 hastanın 4 (\%26)'ünde sigara içme öyküsü olduğu, eksitus olan hastaların hiçbirinde sigara kullanma öyküsünün olmadığı saptanmıştır. Bu bulgular, sigara içmenin COVID-19 riskini artırmadığını düşündürmektedir. Sonuç olarak, tüm dünyayı etkisi altına alan COVID-19 enfeksiyonunun risk faktörleri, bulaş yolları ve klinik özellikleri konusunda yapılan çalışmaların paylaşılarak hastalıkla ilgili bilgi birikiminin hızla artırılması gerekmektedir.

Anahtar kelimeler: Koronavirüs; COVID-19; risk faktörleri; komorbidite.

\section{ABSTRACT}

Coronaviruses are RNA viruses that can cause disease in the upper and lower respiratory tract in humans and animals. Lately, a new coronavirus causing pneumonia cases was detected in Wuhan, China in December 2019. Soon after, the name of the virus was identified as the "severe acute respiratory syndrome coronavirus-2", and the World Health Organization named the disease coronavirus disease-2019 (COVID-19). In our country, the first cases began to appear in the second week of March. In this study, we aimed to investigate the demographic characteristics and risk factors of patients with the diagnosis of COVID-19. A total of 100 patients (53 female and 47 male) were included in our study. The patients included in the study were randomly selected from the registration system and their information was evaluated retrospectively. The mean age of the patients was 54.42 (Age range $=20-90$ ). When the risk factors for catching the disease were evaluated; it was determined that there was at least one risk factor in 46 patients; 30 patients had close contact with the COVID-19 patient in the social environment (30\%) and 16 patients had a travel history outside the city in the last 14 days $(16 \%)$. The most common symptoms in our patients were; cough $(93 \%)$, fever $(42 \%)$, dyspnea $(22 \%)$, weakness $(8 \%)$, sore throat $(7 \%)$, diarrhea $(6 \%)$, headache (5\%) and sputum (2\%). The most common comorbid conditions in our patients were detected as hypertension (42\%), diabetes mellitus (DM) (21\%), congestive heart failure (10\%), allergic asthma (7\%), chronic obstructive pulmonary disease (6\%), rheumatoid arthritis (3\%), coronary artery disease (2\%), solid organ tumour (2\%), depression (1\%) and epilepsy (1\%). The mean age of our 15 patients who were monitored in intensive care unit was 65 y $( \pm 11.46)$, the mean age of 85 patients followed in the service was 52.55 ( \pm $16.35)$ and this difference was statistically significant $(p=0.006)$. When these two groups were compared in terms of comorbid diseases, the presence of DM was $40 \%$ higher $(n=6)$ in intensive care patients, and this difference was statistically significant $(p=0.05)$. In addition, the majority [11 patients $(73 \%)$ ] of the patients hospitalized in the intensive care unit were male $(p=0.03)$. When smoking was evaluated as a risk factor for serious illness, 4 of 11 patients (26\%) in intensive care unit had a smoking history, while none of the patients who have died due to COVID-19 had a smoking history. These findings suggested to us that smoking does not increase the severity of COVID-19 disease. As a result, knowledge about the disease should be increased rapidly by sharing the studies on risk factors, transmission routes and clinical features of COVID-19 infection, which affects the whole world.

Keywords: Coronaviruses; COVID-19; risk factors; comorbidity.

\section{Gíriş}

Koronavirüsler, insan ve hayvanlarda üst ve alt solunum yollarında hastalık oluşturan RNA virüsleridir. İnsan koronavirüsleri, erişkin yaş grubu üst solunum yolu enfeksiyonlarının \%5-10'una neden olurken, özellikle ileri yaş grubunda pnömoniye neden olmaktadır ${ }^{1}$. İnsanlarda genellikle soğuk algınlığı şeklinde hastalığa yol açan dört tür koronavirüs (229E, HKU1, NL63 ve OC43) mevcuttur. Bunların dışında, son yıllarda saptanan SARS-CoV (2002) ve MERS-CoV (2012), ciddi solunum yolu hastalığına ve nozokomiyal salgınlara yol açabilen türler olarak saptanmıştır ${ }^{2}$. Aralık 2019 tarihinde Çin'in Wuhan kentinde kökeni bilinmeyen pnömoni olgularının saptanmasından kısa süre sonra etkenin yeni 
bir koronavirüs olduğu saptanmış ve Dünya Sağlık Örgütü (DSÖ) hastalığa "coronavirus disease-2019 (COVID -19)" adını vermiştir. Kısa süre sonra virüsün adı "severe acute respiratory syndrome coronavirus-2 (SARS-CoV-2)" olarak tanımlanmıştır", . "Coronavirus disease 2019- (COVID-19)" un tanısı, şüpheli olgularda genellikle solunum yolu örneklerinden gerçek zamanlı reverse transkripsiyon polimeraz zincir reaksiyonu (RT-PCR) yöntemi ile SARS-CoV-2'nin saptanmasıyla konulmaktadır ${ }^{5}$. COVID-19 enfeksiyonunda en sık saptanan bulgular; ateş, öksürük, yorgunluk ve dispne olarak bildirilmiştir. Hastalarda en sık görülen komorbiditeler; hipertansiyon, diabetes mellitus, kardiyovasküler hastalıklar ve solunum sistemi hastalıkları olarak bildirilmiştir ${ }^{6}$. Hastalarda gözlenen klinik tablolar farklılık göstermekle birlikte; hastaların \%81'inde hafif-orta şiddette pnömoni, \%14'ünde SARS (dispne, hipoksi, solunum sayısı $\geq 30 / \mathrm{dk}$, oksijen saturasyonu $\leq \% 93$ gibi bulgular), $\% 5$ olguda ise kritik hastalık (solunum yetmezliği veya çoklu organ yetmezliği) tablosu geliştiği bildirilmiş$\mathrm{tir}^{5}$. Bu çalışmada, COVID-19 tanısıyla takip edilen hastaların, sahip oldukları risk faktörleri, klinik bulguları ve komorbiditeleri açııından değerlendirilmesi amaçlanmıştır.

\section{GEREÇ ve YÖNTEM}

Bu çalışma, Sağlık Bakanlığı Samsun Eğitim ve Araştırma Hastanesi Girişimsel Olmayan Klinik Araştırmalar Etik Kurulu onayı ile gerçekleştirildi (Tarih: 20.04.2020, Karar No: GOKA/2020/6/2). Çalışma, T.C. Sağlık Bakanlığı Sağlık Hizmetleri Genel Müdürlüğü Bilimsel Çalışma Platformu aracılığıyla onaylandı (Tarih: 05.05.2020 ve Karar No: Günal2020-05-04T11_08_21.xml).

Çalışmamıza, 1 Mart 2020-1 Mayıs 2020 tarihleri arasında Samsun Eğitim ve Araştırma Hastanesinde Enfeksiyon Hastalıkları ve iç̧ Hastalıkları klinikleri olan Özel-1 ve Özel-2 servislerinde COVID-19 tanısıyla yatan, yaşları 20-90 yıl arasında, 53 kadın ve 47 erkek olmak üzere toplam 100 hasta dahil edildi. Hastalar, kayıt sisteminden retrospektif olarak rastgele seçilen ve yalnız bu kliniklerde takip edilenler arasından seçildi. Hastaların demografik verileri, COVID-19'a yönelik risk faktörleri ve komorbiditeleri dosya bulgusu olarak kaydedildi. Hastaların COVID-19 tanısı; nazofarenks sürüntülerinde Bio-speedy SARS-Cov-2 (2019-nCoV) RT-qPCR detection kit (Bioeksen, İstanbul, Türkiye) kullanılarak testin pozitif saptanması ile konuldu.

\section{İstatistiksel Analiz}

Kategorik değişkenler n, (\%) ve sürekli değişkenler, ortalama \pm standart sapma olarak belirlendi. Gruplar arasında kategorik değişkenlerin karşılaştırılmasında ki-kare testi, sürekli değişkenlerin karşılaştırılmasında ise Student's t-testi kullanıldı. $p<0.05$ düzeyi istatistiksel olarak anlamlı kabul edildi.

\section{BULGULAR}

Çalışmaya 53'ü kadın, 47'si erkek toplam 100 hasta dahil edilmiştir. Hastaların yaş ortalaması 54.42 (20-90) yıl olarak belirlenmiştir. Hastalığın olası risk faktörleri değerlendirildiğinde, 46 hastanın bir risk faktörüne sahip olduğu saptanmıştır. Bu risk faktörleri; COVID-19 hastası ile sosyal ortamda yakın temas (\%30) ve son 14 gün içerisinde seyahat 
öyküsü (\%16) olarak belirlenmiştir. Enfeksiyon öncesi seyahat öyküsü sorgulandığında; 9 (\%56.2) hastanın bir Avrupa ülkesinden, 7 (\%43.8) hastanın ise umreden dönüş öyküsü olduğu saptanmıştır.

Hastalarımızda en sık saptanan komorbiditeler; hipertansiyon (HT) (\%42), diabetes mellitus (DM) (\%21), konjestif kalp yetmezliği (KKY) (\%10), alerjik astım (\%7), kronik obstrüktif akciğer hastalığı (KOAH) (\%6), romatoid artrit (RA) (\%3), koroner arter hastalığı (KAH) (\%2), solid organ tümörü (\%2), depresyon (\%1) ve epilepsi (\%1) olarak belirlenmiştir (Tablo I).

Hastaların 85'i klinik serviste, 15'i yoğun bakım şartlarında takip edilmiştir. Yoğun bakımda izlenen hastalarımızın yaş ortalaması 65 ( \pm 11.46$)$ yıl, serviste takip edilen hastaların yaş ortalaması ise 52.55 ( \pm 16.35) yıl olarak saptanmış ve aradaki bu fark istatistiksel olarak anlamlı bulunmuştur ( $\mathrm{p}=0.006)$. Yoğun bakımda yatan hastaların $11(\% 73)^{\prime} \mathrm{i}$, servislerde yatan hastaların ise 36 (\%42.3)'sı erkek olup, bu fark istatistiksel olarak anlamlı bulunmuştur ( $p=0.03)$. Bu iki grup komorbidite açısından karşılaştırıldığında, DM varlığı yoğun bakım hastalarında [\%40 $(n=6)]$, servis hastalarına oranla [\%17.6 $(n=15)]$ daha yüksek olup, fark istatistiksel olarak anlamlı bulunmuştur $(p=0.05)$. Bu iki grup arasında yoğun bakım hastalarında HT varlığı (\%60) daha yüksek saptanmakla birlikte, aradaki fark istatistiksel olarak anlamlı bulunmamıştır $(p=0.13)$ (Tablo I).

Hastalarımızda en sık rastlanan semptomlar; öksürük (\%93), ateş (\%42), dispne (\%22), halsizlik (\%8), boğaz ağrısı (\%7), ishal (\%6), baş ağrısı (\%5) ve balgam (\%2)

Tablo I. Hastaların Demografik Verileri ve Komorbidite Durumları

\begin{tabular}{|c|c|c|c|c|}
\hline & $\begin{array}{l}\text { Tüm hastalar } \\
\quad(n=100)\end{array}$ & $\begin{array}{c}\text { Serviste yatan } \\
\text { hastalar }(n=85)\end{array}$ & $\begin{array}{l}\text { Yoğun bakımda } \\
\text { yatan hastalar } \\
(\mathrm{n}=15)\end{array}$ & $\mathrm{p}^{*}$ \\
\hline Yaş (yıl) & 54.42 & 52.55 & 65 & 0.006 \\
\hline \multicolumn{5}{|l|}{ Cinsiyet } \\
\hline Erkek & 47 & 36 & 11 & \\
\hline Kadın & 53 & 49 & 4 & 0.03 \\
\hline \multicolumn{5}{|l|}{ Komorbid hastalıklar } \\
\hline Hipertansiyon & 42 & 33 & 9 & 0.13 \\
\hline Diabetes mellitus & 21 & 15 & 6 & 0.05 \\
\hline Konjestif kalp yetmezliği & 10 & 8 & 2 & 0.64 \\
\hline Alerjik astım & 7 & 6 & 1 & 0.96 \\
\hline Kronik obstrüktif akciğer hastalığı & 6 & 4 & 2 & 0.19 \\
\hline Romatoid artrit & 3 & 3 & 0 & 0.46 \\
\hline Koroner arter hastalığı & 2 & 1 & 1 & 0.16 \\
\hline Solid organ tümörü & 2 & 2 & 0 & 0.55 \\
\hline Depresyon & 1 & 1 & 0 & 0.67 \\
\hline Epilepsi & 1 & 1 & 0 & 0.67 \\
\hline
\end{tabular}




\begin{tabular}{|lc|}
\hline Tablo II. Hastalarda Görülen Semptomlar & \\
\hline Semptomlar & $(\mathbf{n}=\mathbf{1 0 0}) \mathbf{n}(\%)$ \\
\hline Öksürük & $93(93)$ \\
Ateş & $42(42)$ \\
$37-38^{\circ} \mathrm{C}$ & $33(78.5)$ \\
$>38^{\circ} \mathrm{C}$ & $9(21.5)$ \\
Dispne & $22(22)$ \\
Halsizlik & $8(8)$ \\
Boğaz ağrısı & $7(7)$ \\
İshal & $6(6)$ \\
Baş ağrısı & $5(5)$ \\
Balgam & $2(2)$ \\
\hline
\end{tabular}

olarak saptanmıştır (Tablo II). Ateş yüksekliği olan 42 hastanın $33^{\prime}$ ünün ateşi $37-38^{\circ} \mathrm{C}$ arasındayken, dokuz hastada ise $>38^{\circ} \mathrm{C}$ olarak belirlenmiştir (Tablo II).

Tedavi altındaki hastaların 15'inde komplikasyon gelişirken, bunların 11'i akut böbrek yetmezliği, beşi akut respiratuar distress sendromu (ARDS), biri ise miyokart infarktüsü (MI) şeklinde gözlenmiştir. Tedavi edilen hastaların 96'sı şifa ile taburcu edilirken, yoğun bakımda izlenen dört hasta eksitus olmuştur. Hayatını kaybeden hastaların yaş ortalaması 69.74 yıl ve tümü erkek olarak belirlenmiştir.

Hastalarımızın 21'inde sigara içme öyküsü saptanmıştır. Sigara içmenin ciddi hastalık kategorisi açısından bir risk faktörü olup olmadığı değerlendirildiğinde, yoğun bakımda yatan 11 hastanın 4 (\%26)'ünde sigara içme öyküsü varken, serviste takip edilen hastalardan 17 (\%20)'sinde sigara içme öyküsü saptanmıştır. Hayatını kaybeden hastaların hiçbirinde sigara kullanma öyküsü tespit edilmemiştir.

\section{TARTIŞMA}

Çalışmaya dahil edilen 53 kadın, 47 erkek hastanın yaş ortalaması 54.42 (20-90) yıl olup, \%15'i yoğun bakım şartlarında tedavi edilmiştir. Guan ve arkadaşları yaptıkları çaışmada ${ }^{7}$, hastaların yaş ortalamasının 47, \%41.9'unun kadın, yoğun bakıma yatış oranının ise \%5 olduğunu bildirmişlerdir.

SARS-CoV-2'nin insandan insana bulaşı, hastalardan etrafa saçılan enfekte damlacıkların mukozalarla teması veya solunması, fekal veya intrauterin geçiş yoluyla olabilmekte$\mathrm{dir}^{2}$. Bu nedenle, insandan insana bulaş esas olarak, hastalarla ve onların enfekte çıkartılarıyla korunmasız yakın temas ile olmakla birlikte, aile üyesi ve/veya arkadaşlar arasındaki inkübasyon döneminde bulunan taşıyıcı kişilerle yakın temasta bulunmakla gerçekleşmektedir $^{8}$. Hastalarımızdan 46'sında en az bir risk faktörü olduğu saptanırken, bu risk faktörleri; COVID-19 hastası ile sosyal ortamda yakın temas etme (\%30) ve son 14 gün içerisinde seyahat öyküsü (\%16) olarak belirlenmiştir. COVID-19 salgınının ülkemizde 
tanımlanmasından önce Avrupa ve bazı Orta Asya ülkelerinde görülmeye başlamasından dolayı hastalarımızın seyahat öyküsü detaylı olarak incelendiğinde; dokuz (\%56.2) hastanın bir Avrupa ülkesine seyahat ve yedi (\%43.8) hastanın ise umreden dönüş öyküsü olduğu saptanmıştır.

Çin'de yapılan çalışmalarda, hastalarda komorbidite açısından en sık hastalık HT (\%23.2) ve DM (\%10.9) olarak saptanmıştır ${ }^{9,10}$. Yang ve arkadaşlarının yaptıkları bir meta-analizde ${ }^{6}$ en sık görülen komorbiditelerin HT, DM, kardiyovasküler hastalıklar ve solunum sistemi hastalıkları olduğu bildirilmiştir. Bu çalışmada, hastaların ileri yaş grubunda ve komorbid olmalarının ciddi hastalık tablosuyla ilişkili olabileceği belirtilmiştir. Çalışmamızda da benzer olarak, hastalarımızda en sık komorbiditeler; HT (\%42), DM (\%21), KKY (\%10), alerjik astım (\%7), KOAH (\%6), RA (\%3), KAH (\%2), solid organ tümörü (\%2), depresyon (\%1) ve epilepsi (\%1) olarak saptanmıştır. Ciddi hastalık ve ölüm riskinin HT olanlarda, olmayanlara göre 2.5 kat yüksek olduğu bildirilmiştir ${ }^{11}$. Çalışmamızda eksitus olan hastalarımızın üçünde DM, ikisinde HT ve birinde KAH varlığı saptanmıştır.

Çalışma grubumuzdaki hastaların 85'i klinik serviste takip edilirken, 15'i yoğun bakım şartlarında takip edilmiştir. Yoğun bakımda izlenen hastalarımızla serviste yatan hastalarımız arasında yaş ortalaması ve cinsiyet açısından istatistiksel fark bulunmuştur [sırasıyla; 65 ( \pm 11.46$), 52.55$ ( \pm 16.35$),(p=0.006)]$. Yoğun bakımda yatan hastaların $11(\% 73)^{\prime} i$, servislerde yatan hastaların ise 36 (\%42.3)'sı erkek olup, bu fark istatistiksel olarak anlamlı bulunmuştur $(p=0.03)$. Bu iki grup komorbidite açısından karşılaştırıldığında DM varlığı açısından anlamlı bir fark olduğu görülmüştür [yoğun bakım hastaları; \%40 (n= $6)$, servis hastaları; \%17.6 $(n=15),(p=0.05)]$. Bu iki grup arasında yoğun bakım hastalarında HT varlığı (\%60) daha yüksek saptanmakla birlikte, bu fark istatistiksel olarak anlamlı bulunmamıştır $(p=0.13)$.

Guan ve arkadaşları ${ }^{7}, 1.099$ hasta ile yaptıkları çalışmada, yoğun bakım $(n=173)$ ve serviste yatan $(n=926)$ hastaların yaş ortalamasını, sırasıyla 52 ve 45 yıl olarak saptarken, yoğun bakım ve servis hastalarının kadın olma oranlarını, sırasıyla \%42.2 ve \%41.8 olarak belirlemiş ve bu açıdan hastalar arasında istatistiksel bir fark olmadığını bildirmişlerdir. Bu çalışmada, yoğun bakımda yatan hastalarda en sık komorbiditenin HT (\%23.7) ve DM (\%16.2) olduğu saptanmıştır.

COVID-19 enfeksiyonunda en sık saptanan bulgular; ateş, öksürük, yorgunluk ve dispne olarak bildirilmiştir ${ }^{6}$. Huang ve arkadaşlarının 41 hasta ile yaptıkları çalışmada ${ }^{5}$, en sık semptomlar; ateş (\%98), öksürük (\%76), kas ağrısı veya yorgunluk (\%44) olarak bildirilmiştir. Guan ve arkadaşlarının yaptığı çalışmada ${ }^{7}$ ise en sık saptanan semptomlar; ateş (\%88.7), öksürük (\%67.8), yorgunluk (\%38.1), balgam (\%33.4), nefes darlığı (\%18.6), öksürük (\%13.9) ve baş ağrısı (\%13.6) olarak bildirilmiştir. Çalışmamızda da hastalarımızda en sık rastlanan semptomlar; öksürük (\%93), ateş (\%42), dispne (\%22), halsizlik (\%8), boğaz ağrısı (\%7), ishal (\%6), baş ağrısı (\%5) ve balgam (\%2) olarak saptanmıştır. 
Tedavi altındaki hastaların 12'sinde komplikasyon gelişirken; bunların 11'inde akut böbrek yetmezliği, beşinde ARDS, birinde ise MI gözlenmiştir. Tedavi edilen hastaların 96'sı şifa ile taburcu edilirken, yoğun bakımda yatan hastalardan dördü eksitus olmuştur. Huang ve arkadaşlarının 41 hasta ile yaptıkları çalışmada ${ }^{5}$, hastaların \%29'unda ARDS, \%15'inde anemi, \%12'sinde MI ve \%10'unda sekonder bakteriyel enfeksiyon geliştiği bildirilmiştir. Aynı çalışmada hastaların \%32'sinin yoğun bakımda takip edildiği ve bunların altısının (\%15) eksitus olduğu izlenmiştir. Çalışmalarda en sık görülen komplikasyonların akut solunum yetmezliği, şok, akut böbrek yetmezliği, MI ve sekonder bakteriyel enfeksiyonlar olduğu bildirilmiştir ${ }^{12}$. DSÖ, nisan ayında hastalığın mortalitesini \%6.3 olarak açıklamıştır ${ }^{13}$. Türkiye'de mortalite oranı ise \%2.1 olarak bildirilmiştir ${ }^{2}$. Çalışmalarda mortaliteyi etkileyen pek çok neden olmakla birlikte, en önemli faktörlerin komorbidite ve yaş olduğu bildirilmiştir ${ }^{14}$. Çalışmamızda da eksitus olan hastalarımızın yaş ortalaması 69.74 (54-87) yıl iken, bu dört hastanın üçünde HT, ikisinde DM varlığı saptanmıştır. Her yaşta COVID-19 bildirilmesine rağmen ileri yaştaki hastalar enfeksiyona daha duyarlı görünmektedir. Bazı çalışmalar, en çok etkilenen yaş grubunun orta yaş aralığındaki (30-80 yaş arası) bireyler olduğunu göstermektedir ${ }^{2}$. Çalışmamıza dahil edilen 100 hastanın yaş ortalaması 54.42 (20-90) yıl iken, eksitus olan dört hastamızın yaş ortalaması 69.74 (5487) olarak tespit edilmiştir.

Yapılan meta-analizlerde, sigara içilmesi, ciddi hastalık ve hastaneye yatış gerektiren durumları artıran nedenlerden biri olarak gösterilmektedir ${ }^{15}$. Guan ve arkadaşları yaptıkları çalışmada ${ }^{7}$, yoğun bakım hastalarının \%16.9'unun, serviste yatan hastaların \%11.8'inin sigara kullandığını ve bu iki grup arasında istatistiksel bir fark olmadığını bildirmişlerdir. Lippi ve arkadaşları da yaptıkları çalışmada ${ }^{16}$ aktif sigara içicisi olmanın COVID-19 enfeksiyonunun ciddiyeti ile ilişkisi olmadığını bildirmişlerdir. Hastalarımızın 21'inde sigara içme öyküsü saptanmıştır. COVID-19'a bağlı ciddi hastalığın ortaya çıkmasında sigara içilmesinin bir risk faktörü olup olmadığı değerlendirildiğinde, yoğun bakımda yatan 11 hastanın dördünde \%26) sigara içme öyküsü varken, ölen hastaların hiçbirinde sigara kullanma öyküsü bulunmamıştır. Bu bulgular, sigara içmenin COVID-19 hastalığının ciddiyetini artırmadığını düşündürmüşsür.

Sonuç olarak, tüm dünyayı etkisi altına alan COVID-19 enfeksiyonunun risk faktörleri, bulaş yolları ve klinik özellikleri konusunda yapılan çalışmaların paylaşılarak hastalıkla ilgili bilgi birikiminin hızlı bir şekilde artırılması gerekmektedir. Bu çalışmada, COVID-19 enfeksiyonu ile ilişkili risk faktörleri ve klinik özellikler irdelenerek literatüre katkı sağlanmıştır.

\section{ETIK KURUL ONAYI}

Bu çalışma, Sağlık Bakanlığı Samsun Eğitim ve Araştırma Hastanesi Girişimsel Olmayan Klinik Araştırmalar Etik Kurulu onayı ile gerçekleştirildi (Tarih: 20.04.2020, Karar No: GOKA/2020/6/2).

\section{ÇIKAR ÇATIŞMASI}

Yazarlar bu makale ile ilgili herhangi bir çıkar çatışması bildirmemişlerdir. 


\section{KAYNAKLAR}

1. Li Q, Guan X, Wu P, Wang X, Zhou L, Tong, et al. Early Transmission Dynamics in Wuhan, China of Novel Coronavirus Infected Pneumonia. N Engl J Med 2020; 382(13): 1199-1207.

2. Bulut C, Kato Y. Epidemiology of COVID-19. Turk J Med Sci 2020; 50(SI-1): 563-70.

3. Hui DS, E IA, Madani TA, Ntoumi F, Kock R, Dar O, et al. The continuing 2019-nCoV epidemic threat of novel coronaviruses to global health - The latest 2019 novel coronavirus outbreak in Wuhan, China. Int J Infect Dis 2020; 91: 264-6.

4. Lu R, Zhao X, Li J, Niu P, Yang B, Wu H, et al. Genomic characterisation and epidemiology of 2019 novel coronavirus: implications for virus origins and receptor binding. Lancet 2020; 395(10224): 565-74.

5. Huang C, Wang Y, Li X, Ren L, Zhao J, Hu Y, et al. Clinical features of patients infected with 2019 novel coronavirus in Wuhan, China. Lancet 2020; 395(10223): 497-506.

6. Yang J, Zheng Y, Gou X, Pu K, Chen Z, Guo Q, et al. Prevalence of comorbidities in the novel Wuhan coronavirus (COVID-19) infection: a systematic review and meta-analysis. Int J of Infect Dis 2020; 94: 91-5.

7. Guan WJ, Ni ZY, HU Y, Liang WH, Ou CQ, He JX, et al. Clinical characteristics of coronavirus disease 2019 in China. N Engl J Med 2020; 382(18): 1708-20.

8. Guo YR, Cao QD, Hong ZS, Tan YY, Chen SD, Jin HJ, et al. The origin, transmission and clinical therapies on coronavirus disease 2019 (COVID-19) outbreak - an update on the status. Mil Med Res 2020; 7(1): 11.

9. Hu S, Gao R, Liu L, Zhu M, Wang W, Wang Y, et al. Summary of the 2018 report on cardiovascular diseases in China. Chin Circ J 2019; 34: 209.

10. Liu M, Liu SW, Wang LJ, Bai YM, Zeng XY, Guo HB, et al. Burden of diabetes, hyperglycaemia in China from to 2016: Findings from the 1990 to 2016, global burden of disease study. Diabetes Metab 2019; 45(3): 286-93.

11. Lippi G, Wong J, Henry BM. Hypertension and its severity or mortality in coronavirus disease 2019 (COVID-19): a pooled analysis. Pol Arch Intern Med 2020; 130(4): 304-9.

12. Ge H, Wang X, Yuan X, Xiao G, Wang C, Deng T. The epidemiology and clinical information about COVID-19. Eur J Clin Microbiol Infect Dis 2020; 39(6): 1011-9.

13. World Health Organization (WHO). Coronavirus disease 2019 (COVID-19) Situation Report-84. Erişim adresi: https://www.who.int/docs/default-source/coronaviruse/situation-reports/20200413-sitrep-84-covid-19.pdf (Erişim tarihi: 14. 04.2020)

14. Ji Y, Ma Z, Peppelenbosch MP, Pan Q. Potential association between COVID-19 mortality and health-care resource availability. Lancet Glob Health 2020; 8(4): e480.

15. Emami A, Javanmardi F, Pirbonyeh N, Akbari A. Prevalence of underlying diseases in hospitalized patients with COVID-19: a systematic review and meta-analysis. Arch Acad Emerg Med 2020; 8(1): e35.

16. Lippi G, Henry BM. Active smoking is not associated with severity of coronavirus disease 2019 (COVID-19). Eur J Intern Med 2020; 75: 107-8. 